\title{
Contributions of a Teacher Training Program to Inclusive Education ${ }^{1}$
}

\author{
Marivete Gesser ${ }^{2}$, Reginaldo Medeiros Martins ${ }^{2}$ \\ ${ }^{2}$ Universidade Federal de Santa Catarina, Florianópolis-SC, Brazil
}

\begin{abstract}
This study aimed to identify the contributions of the discipline of "Disabilities and Inclusion" offered by the Specialization Course on Gender and Diversity at School (GDS) to promote inclusive educational processes for people with disabilities in basic education. Nine GDS students who were professionals from educational area participated in the research. The information was obtained through a focus group, recorded with the participants' consent and analyzed based on the thematic content analysis method. The results indicated that there was a change in conception of disability, previously based in charitable and/or in biomedical conceptions, now more in line with the Social Model of Disability and with the precepts of the Convention on the Rights of Persons with Disabilities. In addition, the knowledge obtained by the participants contributed to the construction of pedagogical strategies more focused on the inclusion of people with disabilities considering their specificities.
\end{abstract}

Keywords: teacher education, special education, inclusive education

\section{Contribuições de um Programa de Formação de Professores para a Educação Inclusiva}

\begin{abstract}
Resumo: Este estudo teve como objetivo identificar as contribuições da disciplina "Deficiências e Inclusão" do Curso de Especialização em Gênero e Diversidade na Escola (GDE) para a promoção de processos educativos inclusivos às pessoas com deficiência na educação básica. Participaram da pesquisa nove profissionais da área da educação, que foram cursistas do GDE. As informações foram obtidas por meio de grupo focal, gravadas com autorização dos participantes e analisadas com base no método de análise de conteúdo temática. Os resultados indicaram que houve mudança na concepção sobre a deficiência - de predominantemente fundamentada nas concepções caritativa/assistencial e/ou biomédica para mais em consonância com o Modelo Social da Deficiência e com os preceitos da Convenção sobre os Direitos das Pessoas com Deficiência. Além disso, os conhecimentos obtidos pelos participantes contribuíram para a construção de estratégias pedagógicas mais voltadas à inclusão das pessoas com deficiência considerando suas especificidades.
\end{abstract}

Palavras-chave: formação de professores, educação especial, educação inclusiva

\section{Contribuciones de un Programa de Formación de Profesores a la Educación Inclusiva}

\begin{abstract}
Resumen: Este estudio tuvo como objetivo identificar las contribuciones de la disciplina Discapacidad e Inclusión del curso de especialización en Género y Diversidad en Escuela (GDE) a la promoción de procesos de educación inclusiva para personas con discapacidad en la educación básica. Los participantes en el estudio eran nueve profesionales de la educación, estudiantes de lo GDE. Las informaciones se obtuvieron por intermedio de grupos focales, siendo grabadas con el permiso de los participantes y analizadas mediante el método de análisis de contenido. Los resultados indicaron que hubo un cambio en la percepción de la discapacidad -antes mayormente basada en concepciones de caridad/asistencia y/o biomédica para estar más en línea con el modelo social de la discapacidad y de las disposiciones de la Convención sobre los Derechos de las Personas con Discapacidad. Además, los conocimientos adquiridos por los participantes contribuyeron a la construcción de estrategias pedagógicas más inclusivas.
\end{abstract}

Palabras clave: formación de profesores, educación especial, educación inclusiva

Educational practices directed to including people with disabilities in basic education have become increasingly demanded in contemporary context. It occurs because, after years of struggle of disabled people's social movements,

${ }^{1}$ Correspondence address: Marivete Gesser. Universidade Federal de Santa Catarina. Campus Universitário, Trindade. Florianópolis-SC, Brazil. CEP 88.0400-10. E-mail: marivete.gesser@ufsc.br the right to education under the same conditions as people without disabilities is regulated from a legal viewpoint.

It is important to highlight that in 2008 Brazil ratified the Convention on the Rights of Persons with Disabilities (CRPD), which has since acquired the status of Law, resulting in the adjustment of all legislation based on what is established in this Convention. CRPD was constructed based on the authors of the social model of disability of first and second generation. 
The social model of disability emerged as a counterpoint to the biomedical model - which saw disabled people as having problems that needed to be cured or rehabilitated -, and defines disability as the relation between physical, sensory and intellectual impairments and barriers which hinder the participation of people with disabilities in society in equal terms. Therefore, it shifts disability from the biomedical scope to the social context, emphasizing that it is a human right issue (Legislative Decree No. 186, 2008; Diniz, Barbosa, \& Santos, 2010; Gesser, Nuernberg, \& Toneli, 2012).

The social model of disability is expressed by two generations. The first understands disability as a way of social oppression, and emphasizes that removing architectural and physical barriers would enable disabled people to participate in society in the same conditions as people without disabilities. Without denying the first generation contributions, the second generation proposes advances in the debate. Influenced by feminist and culturalist theories, it brings important discussions to the field of studies on disabilities, such as interdependence as a central principle in people's lives, considering their precarious life situation (Pickens, 2015), the debate on the ethics of care (Kittay, 2015), and pain experience (Diniz et al., 2010). In addition, it also highlights disability as a category of analysis to be considered in social studies and practices, since it, when intersecting with gender, sexuality, race, religion and social class, may support oppression and social exclusion processes (Gesser et al., 2012).

The assumptions of the social model of disability presented above may contribute to the construction of educational processes aimed at including students with disabilities, ensuring their participation in the same conditions as the others, as provided for in all legislation approved after the CRPD. Considering disability as a category of analysis and being attentive to the needs that emerge from this condition may contribute to organizing education and recognizing interdependence as part of human relationships.

Furthermore, the assumptions of the Social Model of Disability have been incorporated into the field of Inclusive Education. Inclusive Education, according to Baglieri, Bejoian, Broderick, Connor and Valle (2011), aims to break with normative conceptions of learning based on the medical model, which exclude children that differ from what has been established as a rule to learn and to be in the world. In addition, the authors emphasize that inclusive education is understood as education that allows including all children in the educational system by eliminating the barriers that impede access to knowledge and student participation. It should be aimed at disrupting discriminatory activities and creating structures to recognize and value human diversity.

Difficulties in adapting curricula, promoting classroom participation strategies, adapting tasks, and developing the interest of disabled students are some everyday contextual conflicts that hamper the inclusion process, frequently blaming students with disabilities for their poor performance and integration (Leite, Silva, Mennocchi, \& Capellini, 2011).
There is also lack of clarity about the potential of disabled students and possibilities of doing pedagogical activities to promote inclusion (Matos \& Mendes, 2015). This scenario makes it difficult to eliminate methodological and attitudinal barriers, maintaining the segregation experience in the classroom (Souza \& Macedo, 2012).

Another relevant aspect mentioned in the literature refers to the education professionals' lack of knowledge of legal frameworks, theoretical-methodological bases and public policies for the inclusion of people with disabilities in school. This lack of knowledge makes it difficult to implement professional training initiatives, generates work overload, besides feelings of incapacity and frustration in students and teachers (Matos \& Mendes, 2015; Silveira, Enumo, \& Rosa, 2012).

Teacher training plays a crucial role in the inclusion of people with disabilities in school, since teachers are those responsible for the teaching-learning process. In the classroom, they are the main responsible for identifying specific potentialities of disabled students, making curricular adaptations and creating work strategies (Arruda \& Castanho, 2015; Leite et al., 2011; Omote \& Pereira Junior, 2011).

The "Teacher Training Program on Gender and Diversity at School" (GDS) is part of the initiatives to transform the regular school into a space for learning and respect for differences. This training program, present in several Brazilian states, received an innovative aspect in the state of Santa Catarina, that is, the addition of the discipline of "Disabilities and Inclusion," which aimed at contributing to teacher training with the purpose of assuring implementation of educational policies directed to the inclusion of people with disabilities in school.

The objective of this research was to identify the contributions of the discipline of "Disabilities and Inclusion," offered in the Specialization Course on Gender and Diversity at School (GDS), to promote inclusive basic education processes for people with disabilities. For this purpose, we evaluated which were the contributions of the discipline to changes in the conceptions of disability and creation of pedagogical strategies aimed at inclusion of disabled people, also considering this population's specificities and the rights guaranteed by the official documents destined to this public.

The research has great relevance in the national scenario, since, although the GDS is available in several Brazilian states, the course offered by UFSC was the only one with a discipline on disability in the curricular structure. As for this discipline, it encompassed the following themes: (a) national and international public policies relating to people with disabilities; (b) disability as a category of analysis from social, historical and cultural viewpoint; (c) the field of disability studies and the social model of disability; (d) ableism as a structuring dimension of culture and producer of discrimination and exclusion of people with disabilities; (e) the different barriers present in schools, which hinder the inclusion of people with disabilities; (f) main technologies, social practices, resources and attitudes that assure disabled people's human rights; (g) theoretical and methodological 
assumptions aimed at ensuring disabled people's sexual and reproductive rights at school.

Finally, it should be emphasized that the evaluation of the impact of inclusion of contents related to disability may contribute not only to the discipline improvement in Santa Catarina GDS, but also to the inclusion of this discipline in all other courses offered in Brazil. In addition, it may contribute to the inclusion of the disability theme in professionals' initial and continuing training in areas such as education, health and Human Sciences.

\section{Method}

The research used qualitative approach. The objectives proposed were met by means of a socio-demographic questionnaire and a focus group composed of professionals interested in participating in the research. As for the place, it was decided to perform the research with professionals enrolled in the Specialization Course on Gender and Diversity at School and who had already completed all its theoretical disciplines, including "Disabilities and Inclusion."

\section{Participants}

The research sample consisted of nine professionals working in the public school system in the state of Santa Catarina. As inclusion criteria, they should be regularly enrolled in one of the campi where the GDS was offered, have completed all course disciplines, and with availability to go to the location where the focus group took place.

Eight white women and one white man aged between 24 and 59 years participated in the study, and the working time in the education area ranged from 2 to 20 years. Regarding training, participants had at least one undergraduate degree in the following areas: pedagogy, psychology, social sciences, administration, and physical education.

\section{Instruments}

Socio-demographic questionnaire. The intention was to gather information about the teachers who participated in the research regarding age, schooling, professional training (graduation and specialization), profession, working time in basic education, and race. The accomplishment of this procedure was fundamental to characterize the participants with regard to the difference social markers as proposed by Vencato (2014).

Focus Group: Focus groups are characterized as interviews that are based on the interaction developed within the group. In this data collection procedure it is possible to listen to several people at a time, and identify significant interactions in the group formed (Kind, 2004). The guiding principles were: conceptions of disability learned by participants throughout their life trajectories, contribution of the course to changing conceptions of disability, and creation of educational strategies aimed at inclusion of students with disabilities.

\section{Procedures}

Data collection. All the 152 GDS students were invited to participate in the study, regardless of their training and having or not disabled students in their classes at the time of the research. The invitation for participation in the focus group has been made in a face-to-face course meeting, and reinforced by message sent via e-mail. Twelve people from three different campi where the course was offered answered the email confirming participation, and nine were present on the day of focus group meeting. As soon as the participants arrived at the location where the focus group took place, they were asked to complete a socio-demographic questionnaire which took them about 5 minutes to be answered. Then, the focal group meeting started, with two-hour duration. The focus group was filmed and audio-recorded with participants' consent. It was guided by the researcher responsible for the study, who has degree in Psychology and works as a higher education teacher in this area, with the assistance of a Psychology scholarship student.

Data analysis. Analysis of the material obtained has been done through thematic analysis content (Bardin, 1977/2010). Recurrence of issues that appeared in the focus group was used as a criterion for separating the text into thematic indicators. These indicators were related to the research objectives and allowed the construction of units of meaning that were interconnected, although organized into different categories.

\section{Ethical Considerations}

This research was approved by the Human Research Ethics Committee of the Hematology and Hemotherapy Center of the state of Santa Catarina - HEMOSC, Protocol no. 9231 of June 16, 2015 (CAAE: 41736015.0.0000.0110). All ethical principles recommended by Resolution 466/12 of the National Health Council were ensured. All participants have read and signed the Informed Consent Form, which contained information about the research. Participants were given fictitious names in order to ensure anonymity.

\section{Results and discussion}

The analysis of the information indicated three central axes. One of them identifies the different conceptions of disability that were part of participants' life history and the problematization of these conceptions. A second axis is related to the contribution of the GDS to learning an inclusive perspective of disability. The last axis refers to the reflection on the challenges of inclusion education policy implementation.

\section{Conceptions of disability}

In this unit, we will identify speeches and experiences about the disability present in the contexts in which the 
participants were constituted as subjects and the effects of these on their relationships with people with disabilities. The research data presented understanding of disability associated mainly with punishment, shame and impairment, as well as with the idea that people with disabilities should provoke pity and charity.

The information obtained from the research evidenced that, throughout their life trajectories, the participants learned the disability experience as incapacity to perform different activities or even simple choices. In addition, the disability condition was evaluated as a producer of discrimination, isolation, and life without perspective. This can be seen in Roberta's statement, when she points out that the person with a disability was characterized as "crippled": "Actually, these people have always been excluded, right? They faced a lot of prejudice. For example: 'he's crippled,' as people used to say in the past, right? 'Oh, he isn't useful for anything,' he was like a vegetable; I see it this way, right? From that perspective..." (Roberta, psychologist, pedagogue and teaching assistant).

Feeling of pity and characterization of people with disabilities as being pitiful for their incapacity were also very frequent in participants' statements, as can be seen in Arlete's statement, pedagogue and teacher "... and there was one [person] with mental disability who used a wheelchair. We felt pity for her. We were very sorry ... 'My God! How can she deal with this situation?"'.

Ideas that people with disabilities are incapable and pitiful, allied to a religious conception, are related to the charitable model of disability. Such a model was stimulated by Christianity since the Middle Ages, being rooted in imaginary and social practices. In this model, the disabled person was someone who existed to be cared for, someone without autonomy, subject to pity and zealous by religious and generous people (Lanna Júnior, 2010).

The notion that disabled people were asexual was also present in the social context in which some of the participants grew up. This point is peculiar because it generates a lot of controversy and preconceived speeches, which do not recognize disabled people as worthy of their sexual and reproductive rights, now guaranteed by the Convention on the Rights of Persons with Disabilities (Legislative Decree No. 186, 2008). In this sense, Roberta's statement points to the denial of the right to marry and raise a family: "Older people used to say that thing, 'so-and-so has limitation, will not be anything, will not have family, will not have sex, will not do anything' because is disabled" (Roberta, psychologist, pedagogue and teaching assistant). Ana, social scientist and teacher, brought the report about one of her cousins who is deaf and, even so, got married and had children, highlighting how the people who lived in the community where she grew up though it was strange. According to her statement, 'for that time: 'Wow! Who did this to her?' When she got pregnant, we thought that it would be....that she would be dependent, that her daughter could have health problems, and everything else."
Prejudice about sexuality of people with disabilities is based on the idea that there is a correct and standard way of relating sexually. Several myths about this issue were indicated by Maia and Ribeiro (2010). It is important to emphasize in this study that the social construction of a normal and happy sexuality notion produces the effect of characterizing any variation as abnormal. Gesser and Nuernberg (2014) emphasize the importance of deconstructing normative standards of sexuality, highlighting that psychology can contribute, through its practices, to helping people with disabilities construct creative and unique ways of experiencing this dimension of life.

Some focus group participants also presented understanding of disability based on religious interpretations, as a result of divine punishment, and of the disabled person's family as a burden-bearer, as one participant testified. "Wow! When I saw a handicapped person, the first thing that came to mind was: 'My God! What have they done to deserve that, this burden, this weight?"' (Roberta, psychologist, pedagogue and teaching assistant). Understanding a person with a disability as hypersexuated was also present in the social imaginary, according to the following statement:

I'd say I've already heard worse things... as I came from a traditional Catholic family, a family that had a person with special needs at the time ... "Oh! There is sin in that family! This is punishment from God! They have to be purified, then they have that kind of child..." And it creates a world without perspective in people's imaginary, because the parents say this kind of things to us, say that this thing is a sin, that God is punishing that family! They have no concept of what it creates in people's minds ... (Maria, physical education teacher).

Understanding disability as associated with the charitable model, which is grounded on Christian discourse, was dominant in respondents' childhood. This interpretation was only questioned from the development of the biomedical model (Diniz et al., 2010). The idea that disability was the manifestation of the devil or divine punishment remained for centuries, and still haunts us, condemning people with disabilities as useless and rejected (Nunes, Saia, \& Tavares, 2015).

Fear of people with disabilities was also present in participants' life experiences, and this idea was stimulated by relatives and people in the community in general. This fear was related to the strangeness caused by the disability with regard to behavior and unusual physical appearance. The idea that people with disabilities are hypersexuated was also part of the social imaginary, as declared in one of the participants' statement: “And I have listened a lot to this kind of conversations... 'do not get too close to him because he's a pervert.' There was the stigmatization of people with Down Syndrome as being perverts." (Júlia, social scientist, pedagogue and teacher).

An interpretation of fear related to the sexuality of people with disabilities is well explained by Maia and 
Ribeiro (2010, p. 163), when noting that there is an "attitude of denial," as attempt not to identify themselves and to move away from that body that is not part of the standard. This refers to the fragility and vulnerability of the human condition, finding that frequently causes negative affects and detachment.

Fear of being sexually assaulted by a disabled person, usually with Down Syndrome, as it appears in the statement, may also provide the idea that such people are hypersexuated, and that a satisfactory sexual practice is not within their reach (Maia \& Ribeiro, 2010). However, these ideas should be deconstructed so that this population's sexual and reproductive rights can be assured.

In this topic, we sought to identify the conceptions of disability that were present throughout participants' life trajectories, and which were adopted by them. In the following topic we will try to highlight the contributions of the discipline of "Disabilities and Inclusion" to stimulating changes in participants' practice conceptions.

\section{Contribution of the discipline of "Disabilities and Inclusion" to adoption of an education inclusive perspective}

In this thematic axis, the contributions of the discipline of "Disabilities and Inclusion," offered in the GDS, will be presented to deconstruct prejudiced and ableism perceptions related to disability, as well as assisting teachers in the construction of practices that are in accordance with the current legislation. Considering that there is no dissociation between thinking, feeling and acting (Zanella \& Molon, 2007), and that the perspective on disability mediates pedagogical practices, it is paramount to identify changes in conceptions and practices related to disability.

Participants' statements evidenced that the knowledge obtained in the GDS in general, and in the discipline of "Disability and Inclusion" specifically, contributed a great deal to them to deconstruct the speeches that associate disability with incapacity, tragedy, punishment and other conceptions that were part of their histories, and constituted them.

Thus, interviewees' speeches reveal that access to knowledge and reflections on disability can contribute to the construction of a more inclusive society, indicating that this concept of disability grounded on the Social Model should be presented as soon as possible for all people, according to statements:

We have a viewpoint before starting the course, and another after it... If I had had this viewpoint since childhood, I could have helped to improve a lot of things (Carla, pedagogue and teacher).

The discipline experience is taking me back to the past, making me to remember how it was the coexistence [with disabled people], and how the family treated [those people]. Thus, it has been very enriching for me... the texts ... and even transforming how we see people with disabilities (Ana, social scientist and teacher).

Other evidence of GDS contribution was the resignification of disability-related perceptions and attitudes, contributing to more inclusive ways of treatment and coexistence with people with disabilities, which demonstrates that attitudinal barriers could be overcome. This could be identified in the following statements:

I'll give a very quick example of what happened to me ... I was with a girl with mild disability, and she's fourteen. Then, she came to school and started saying she was in love with a boy, and that kind of teenagers' thing. Then I started accepting it in a better way, you know? The texts that we read...anyway! In short...it is possible for her to fall in love, she can have a crush on someone, she can date someone, you know? She is a person who will do the same things as we do (Roberta, psychologist, pedagogue and teaching assistant).

My perspective has broadened, right? Deeply [...] Now I think differently! I think I have to get close to him [disabled student], right? Do not be afraid, do not walk away, try to understand his case, and then talk to him, try to take him closer (Arlete, pedagogue and teacher).

According to Amaral (1998), understanding the concept of attitudinal barriers which are characterized as protection and expressed by means of prejudices, stigmas and myths that affect people with disabilities, marking their social exchanges negatively, stimulated new ways of relating to disabled people, as reported by the focal group participants. In some statements, it is possible to see the comprehension of the concept and the materiality of it acting in the daily routine. This can be observed in several participants' statements, who, before the course, saw accessibility as more related to architectural barriers. However, from the course, they could also perceive the existence of attitudinal barriers as well as the importance of breaking them. Still on the attitudinal barriers, Maria's statement stressed that the person who works with people with disabilities needs to be free of prejudice. According to her: "The person who works with disabilities should have a laid back attitude. You have to get rid of prejudices. I thought I was open-minded, but then I saw I was not! After several readings ... 'man, I'm still biased!"” (Maria, physical education teacher).

The critique of ableism, which, according to Mello (2016, p. 3266), consists of a category "materialized through prejudicial attitudes that hierarchize individuals according to the adequacy of their bodies to an ideal of beauty and functional capacity" was also subject to problematization by the students. Julia's statement signals this question: "I think ableism issue as well, standardization, thinking that this person has to be as the others, wanting that disability to 
be overcome, and not to comprehend it in the whole" (Júlia, social scientist, pedagogue and teacher).

From the statements, it is possible to affirm that the course provided theoretical instrumentalization to problematize the culture of normality and attitudinal barriers, provoking the construction of a new conceptual mosaic of disability, which is understood as "an experience of inequality shared by people with different types of impairments" (Diniz et al., 2010, p. 105). Such diversity of impairments is part of the vulnerable and unpredictable human condition, increasingly evidenced by the process of global aging and new needs present in this phase of life.

The reflection on attitudinal barriers was an element that permeated most of the speeches. In the statements, disability started being considered not only a reservoir of impairments to a supposed normal life, but merely a variety of aesthetic and subjective experiences of comprehending the world, corroborating with the undeniable condition of "equality by interdependence," to which we are all subject (Diniz, 2007, p. 67).

The statements pointed out that the discipline of "Disabilities and Inclusion," included in the Specialization Course on Gender and Diversity at School, contributed to break with the attitudinal barriers that act as obstacles to the inclusion of people with disabilities in school. In the World Report on Disability, several studies in different countries have also shown that the attitudes of health professionals towards people with disabilities have changed after the participation in courses, disciplines or short classes on the subject (World Health Organization, 2011).

On the way to a better theoretical and practical instrumentalization, the statements also showed the experience of attending the discipline of "Disabilities and Inclusion" as being positive to add knowledge to personal life and to a teaching-learning relationship that is able to address the needs of students with disabilities. In this sense, one of the participants emphasizes the importance of understanding the difference between integration and inclusion, aspect approached in the course: "The key point for me was to really understand the difference between integration and inclusion. We always think that [if] the student is the room, he is included, and that everything is working. But it's not quite like that, right?" (Júlia, social scientist, pedagogue and teacher). In general, the participants emphasized that nowadays they are more sensitive to the reception of differences, which facilitated a change of attitude towards students with disabilities, according to a participant's statement: "Today, I feel much more sensitive to these people. And in the classroom too, I look at them differently after having all this experience; I'm more available" (Ana, social scientist and teacher).

The experiences and speeches brought by the participants revealed the understanding of a critique of the culture of normality, according to the second generation of the Social Model of Disability. This model of understanding disability highlights the complexity of the disability experience, considering the diversity of ways of being in the world and the interdependence relationships inherent in social life.

\section{Perceptions and difficulties about inclusion education policies and emerging challenges}

In this latter axis, statements and discussions will be presented, which highlight unmet needs to implement the national inclusion policy, leading to violations of human rights in the school context. On this topic, the statements mainly emphasize little or no previous training on the subject and, as a result, difficulty of creating pedagogical strategies aimed at meeting the needs of students with disabilities, as well as the lack of institutional support.

One of the difficulties identified by the focus group participants is the precarious training to deal with students with disabilities in the classroom. Here are some statements that clearly show this question:

And what happens ... we have the equipment, we have the students, but the teachers we have today do not know how to deal with these students, even because this is not approached in the undergraduate courses. Then, the teacher arrives in the classroom, there is a blind student, and the teacher does not know what to do... (Júlia, social scientist, pedagogue and teacher).

We have an inclusion program, and our school is inclusive in terms of architecture; it has access, has everything, the problem is the training of the teacher that will work with students, and then school management makes the difference (Beatriz, psychologist and teaching assistant).

What these teachers show is not only lack of training, but also lack of experience with students with disabilities. Omote and Pereira Junior (2011) emphasize that the experience acquired in teaching influences attitudes towards inclusion. Training for inclusive education is not just understanding technological tools for inclusion, but includes learning a care attitude as well.

Arruda and Castanho (2015) also mention the failure of teacher academic formation and the consequent lack of available knowledge to proceed in a pedagogical and coherent way. The authors also state that the existence of laws does not guarantee inclusion. Therefore, it is necessary a joint social awareness on the theme of promoting continuing training in line with the challenges of inclusion policy.

One difficulty regarding the inclusion educational policy mentioned by the participants is to obtain funds to make the necessary adjustments to the inclusion of students with disabilities. According to Mary's statement, physical education teacher, "The school has to elaborate a project, specifying what type of disability there is in the school. You wait six months, one year, to get the money, and then you have thirty days to elaborate [the project] at the school, and send the report."

Another difficulty related to the inclusion process refers to the mistaken understanding that only the teaching assistant is responsible for the student with disability, and in the case this professional has not been hired, only the 
teacher in charge of the class in which the student is enrolled is responsible for him/her. Six out of the nine focal group participants reported that there is this understanding at the schools where they work. We selected some statements that highlight this question: "Because the teacher who coordinates the discipline usually does not give much importance to it. And it happens that way: 'You are the teaching assistant and the student is yours, you'll have to get by on your own"” (Roberta, pedagogue, psychologist and teacher assistant). "They come to the teacher and say: "This is the content of this week" (Maria, physical education teacher). "Why so much? And the school management gave me a pat on the back, saying: 'We cannot do anything!' Understood?" (Arlete, pedagogue and teacher).

The National Policy on Special Education in the Perspective of Inclusive Education (Ministry of Education, 2008) assumes that the student with a disability is the responsibility of the school and everyone should participate in the inclusion process. However, what was identified through the statements was the lack of articulation and joint planning among the school social actors for the implementation of the policy.

In addition, the way in which teaching is organized ends up contributing to turn the experience of teachers who work with students with disabilities into a solitude experience. The following statement makes this clear: "The principal said: 'Oh, I'm sorry, but we cannot help you!' And he [the disabled student] did not have a second teacher either' (Arlete, pedagogue and teacher).

In contrast to the question raised by Arlete's statement, Almeida, Paula, Silva, Vilela and Neves (2011) affirm that a formative process to receive and educate students with disabilities cannot be restricted to teachers, but should be oriented to all involved in the educational process. Another recurring point in the statements was the lack of spaces for dialogue and experience exchange. Thus, it is emphasized the importance of having, in schools, interdisciplinary spaces of conversations and orientations directed to the promotion of a culture of inclusion.

Matos and Mendes (2015) indicate many items set forth in the Special Education Policy that have not been put in practice. Among them, the authors highlight lack of teacher training on the subject, lack of knowledge of the responsibilities of the various school professionals, and lack of joint work of educators and school managers. Failure to implement this policy has serious consequences for teacher working conditions, and makes the care for disabled students to be precarious. The possibilities of developing different pedagogical strategies are directly affected by the lack of orientations and team planning (Leite et al., 2011).

The information obtained in this research evidenced that the addition of the discipline of "Disabilities and Inclusion" to the Specialization Course on Gender and Diversity at School, offered by UFSC with funding from the Ministry of Education, contributed to changing participants' conceptions of disability. These, which were initially predominantly based on charitable/medical and/or biomedical conceptions, after participation in the course started approaching the precepts of the Convention on the Rights of Persons with Disabilities. Considering that educators' conceptions of disability constitute their practices in the classroom, this research evidenced the relevance of the educational policies to guarantee the inclusion of the disability theme both in teacher initial formation and in teacher continuing formation.

Considering that the research data presented intersections of disability with religion, gender and sexuality issues, as well as association of the condition of disability with lack of capacity, it is paramount disability theme approach in teacher training courses based on intersectional perspective and inclusive education policy. It, starting from the criticism of the speeches directed to disability infantilization, pathologization and medicalization, emphasizes how it is important for the school to be prepared for the reception of differences. Moreover, this perspective considers disability as a category of analysis which, in the intersection with the social markers of race, gender, sexuality, generation, social class and religion, can contribute to oppression and social exclusion processes. In addition, it points to the need for breaking with the barriers that impede the access and permanence of students with disabilities at different levels of education.

The study also showed the importance of teacher training courses based on the reality into which teachers are inserted, and which consider their learning on disabilities obtained along their life trajectories as well as favoring the perception of how these learning constitute their practices in the classroom. Although the information obtained in this study has met its objectives, it is believed that more meetings with the group of participating teachers could have further expanded the understanding of the phenomenon studied. It is also worth mentioning the need for developing more studies related to the disability issue, especially giving visibility to the trajectories of students with disabilities at different levels of education, since the political movement of people with disabilities has been claiming rights based on the following motto "Nothing About Us Without Us."

\section{References}

Almeida, L. A. D., Paula, T. S., Silva, M. F., Vilela, E. M., \& Neves, J. A. B. (2011). Desempenho de alunos com deficiência na rede regular de ensino: Impactos da infraestrutura de acessibilidade e da formação docente [Performance of students with disabilities in the regular education network: Impacts of the infrastructure of accessibility and of the teacher's training]. Pesquisas e Práticas Psicossociais, 6(1), 16-28. Retrieved from https://www.researchgate.net/publication/309676375

Amaral, L. A. (1998). Sobre crocodilos e avestruzes: Falando de diferenças físicas, preconceitos e sua superação [About crocodiles and ostriches: Talking about physical differences, prejudices and overcoming]. In J. G. Aquino (Org.), Diferenças e preconceitos na escola [Differences and prejudices in school] (8th ed., pp. 11-30). São Paulo, SP: Summus. 
Arruda, I. V., \& Castanho, M. I. S. (2015). Inclusão de alunos deficientes mentais em escolas regulares: Sentidos produzidos por professoras de escolas regulares e especial [Inclusion of intellectual disability students in regular schools: Senses produced by teachers of regular and special schools]. Construção Psicopedagógica, 23(24), 20-40. Retrieved from http://pepsic.bvsalud.org/scielo.php?script $=$ sci_ arttext\&pid=S1415-69542015000100003

Baglieri, S., Bejoian, L. M., Broderick, A. A., Connor, D. J., \& Valle, J. (2011). [Re]claiming "Inclusive Education" toward cohesion in educational reform: Disability studies unravels the myth of the normal child. Teachers College Record, 113(10), 2122-2154.

Bardin, L. (2010). Análise de conteúdo [Content analysis] (L. A. Reto \& A. Pinheiro, Trans.). Lisboa, Portugal: Edições 70. (Original work published 1977).

Decreto Legislativo No. 186, de 9 de julho de 2008. (2008, 10 de julho). Aprova o texto da Convenção sobre os Direitos das Pessoas com Deficiência e de seu Protocolo Facultativo, assinados em Nova Iorque, em 30 de março de 2007 [Approves the text of the Convention on the Rights of Persons with Disabilities and its Optional Protocol, signed in New York, on March 30, 2007]. Diário Oficial da União, seção 1. Retrieved from http:// www2.senado.leg.br/bdsf/bitstream/handle/id/99423/ Decreto186_2008_aprova_Convencao_direito_pessoas_ deficiencia.pdf? sequence $=3$

Diniz, D. (2007). O que é deficiência? [What is disability?]. São Paulo, SP: Brasiliense.

Diniz, D., Barbosa, L., \& Santos, W. (2010). Deficiência, direitos humanos e justiça [Disability, human rights and justice]. In D. Diniz \& W. Santos (Orgs.), Deficiência $e$ discriminação [Disability and discrimination] (pp. 97-115). Brasília, DF: EdUnB.

Gesser, M., \& Nuernberg, A. H. (2014). Psicologia, sexualidade e deficiência: Novas perspectivas em direitos humanos [Psychology, sexuality and disability: New perspectives on human rights]. Psicologia: Ciência e Profissão, 34(4), 850-863. doi:10.1590/1982370000552013

Gesser, M., Nuernberg, A. H., \& Toneli, M. J. F. (2012). A contribuição do modelo social da deficiência à psicologia social [The contribution of the social model of disability to the social psychology]. Psicologia e Sociedade, 24(3), 557-566. doi:10.1590/S0102-71822012000300009

Kind, L. (2004). Notas para o trabalho com a técnica de grupos focais [Notes for the work with focus group technique]. Psicologia em Revista, 10(15), 124-136. Retrieved from http://periodicos.pucminas.br/index.php/ psicologiaemrevista/article/view/202/213
Kittay, E. F. (2015). Centering justice on dependency and recovering freedom. Hypatia, 30(1), 285-291. doi:10.1111/hypa.12131

Lanna Júnior, M. C. M. (Comp.). (2010). História do movimento político das pessoas com deficiência no Brasil [History of the political movement of people with disabilities in Brazil]. Brasília, DF: Secretaria Nacional de Promoção dos Direitos da Pessoa com Deficiência. Retrieved from http://www.pessoacomdeficiencia. gov.br/app/sites/default/files/publicacoes/historia-domovimento-politico-pcd.pdf

Leite, L. P., Silva, A. M., Mennocchi, L. M., \& Capellini, V. L. M. F. (2011). A adequação curricular como facilitadora da educação inclusiva [The curricular adequacy as a facilitator of inclusive education]. Psicologia da Educação, (32), 89-111. Retrieved from http://pepsic.bvsalud.org/scielo.php?script=sci arttext\&pid=S1414-69752011000100006

Maia, A. C. B., \& Ribeiro, P. R. M. (2010). Desfazendo mitos para minimizar o preconceito sobre a sexualidade de pessoas com deficiências [Dispelling myths to minimize prejudice about the sexuality of people with disability]. Revista Brasileira de Educação Especial, 16(2), 159176. doi:10.1590/S1413-65382010000200002

Matos, S. N., \& Mendes, E. G. (2015). Demandas de professores decorrentes da inclusão escolar [Teacher demands resulting from school inclusion]. Revista Brasileira de Educação Especial, 21(1), 9-22. doi:10.1590/S1413-65382115000100002

Mello, A. G. (2016). Deficiência, incapacidade e vulnerabilidade: Do capacitismo ou a preeminência capacitista e biomédica do Comitê de Ética em Pesquisa da UFSC [Disability, inability and vulnerability: On ableism or the pre-eminence of ableist and biomedical approaches of the Human Subjects Ethics Committee of UFSC]. Ciência \& Saúde Coletiva, 21(10), 3265-3276. doi:10.1590/1413-812320152110.07792016

Ministério da Educação. (2008). Política Nacional de Educação Especial na Perspectiva da Educação Inclusiva: Documento elaborado pelo Grupo de Trabalho nomeado pela Portaria Ministerial $n^{\circ} 555$, de 5 de junho de 2007, prorrogada pela Portaria $n^{\circ}$ 948, de 9 de outubro de 2007 [National Policy on Special Education in the Perspective of Inclusive Education]. Brasília, DF: MEC. Retrieved from http://portal.mec. gov.br/arquivos/pdf/politicaeducespecial.pdf

Nunes, S. S., Saia, A. L., \& Tavares, R. E. (2015). Educação inclusiva: Entre a história, os preconceitos, a escola e a família [Inclusive education: History, prejudices, and school and family]. Psicologia: Ciência e Profissão, 35(4), 1106-1119. doi:10.1590/1982-3703001312014 
Omote, S., \& Pereira Junior, A. A. (2011). Atitudes sociais de professoras de um município de médio porte do Paraná em relação à inclusão [Social attitudes of teachers from a mid size town in the State of Parana toward inclusion]. Pesquisas e Práticas Psicossociais, 6(1), 7-15. Retrieved from http://repositorio.unesp.br/bitstream/ handle/11449/115350/ISSN18098908-2011-06-01-0715.pdf? sequence $=1 \&$ isAllowed $=\mathrm{y}$

Organização Mundial da Saúde. (2011) shows. Relatório mundial sobre a deficiencia [World report on disability] (Lexicus Serviços Linguísticos, Trans.]. São Paulo: SEDPcD. Retrieved from http://www. pessoacomdeficiencia.sp.gov.br/usr/share/documents/ RELATORIO_MUNDIAL_COMPLETO.pdf

Pickens, T. A. (2015). Octavia Butler and the aesthetics of the novel. Hypatia, 30(1), 167-180. doi:10.1111/hypa.12129

Silveira, K. A., Enumo, S. R. F., \& Rosa, E. M. (2012). Concepções de professores sobre inclusão escolar e interações em ambiente inclusivo: Uma revisão da literatura [Conceptions of teachers on school inclusion and inclusive environment interactions: A review of the literature]. Revista Brasileira de Educação Especial, 18(4), 695-708. doi:10.1590/S1413-65382012000400011

Souza, A. M. L., \& Macedo, M. C. S. R. (2012). Avaliação da aprendizagem e inclusão escolar: A singularidade a serviço da coletividade [Learning assessment and school inclusion: Uniqueness in the service of collectivity]. Psicologia Escolar e Educacional, 16(2), 283-290. doi:10.1590/S1413-85572012000200011

Vencato, A. P. (2014). Diferenças na escola [Differences in school]. In R. Miskolci \& J. Leite Júnior (Orgs.), Diferenças na educação: Outros aprendizados [Differences in education: Other learning] (pp. 19-56). São Carlos, SP: EdUFSCar.

Zanella, A. V., \& Molon, S. I. (2007). Psicologia (em) contextos de escolarização formal: Das práticas de dominação à (re)invenção da vida [Psychology and (in) contexts of formal schooling: Practices of domination and (re)invention of life]. Contrapontos, 7(2), 255-268. Retrieved from https://siaiap32.univali.br/seer/index. php/rc/article/view/904/758

Marivete Gesser is a Professor of the Departamento de Psicologia at Universidade Federal de Santa Catarina, Florianópolis-SC, Brazil.

Reginaldo Medeiros Martins is an undergraduate student of the Departamento de Psicologia of the Universidade Federal de Santa Catarina, Florianópolis-SC, Brazil.
Authors' Contribution:

All authors made substantial contributions to the conception and design of this study, to data analysis and interpretation, and to the manuscript revision and approval of the final version. All the authors assume public responsibility for content of the manuscript.

Received: Dec. 21, 2016

1st Revision: May. 08, 2018

Approved: Jun. 13, 2018
How to cite this article:

Gesser, M., \& Martins, R. M. (2019). Contributions of a teacher training program to inclusive education. Paidéia (Ribeirão Preto), 29, e2907. doi: http://dx.doi.org/10.1590/1982-4327e2907 